\title{
ROLE OF FLOODS ON SINKHOLE OCCURRENCE IN COVERED KARST TERRAINS: CASE STUDY OF THE ORLÉANS AREA (FRANCE) DURING THE 2016 METEOROLOGICAL EVENT AND PERSPECTIVES FOR OTHER KARST ENVIRONMENTS.
}

\author{
Gildas Noury \\ BRGM (French Geological Survey), DRP (Risks and Prevention Division), 3 avenue Claude Guillemin, BP 36009 , \\ Orléans,45060,France, g.noury@brgm.fr
}

\section{Jérôme Perrin}

BRGM (French Geological Survey), DI (International Division), 3 avenue Claude Guillemin, BP 36009, Orléans, 45060,France,je.perrin@brgm.fr

\section{Li-Hua Luv}

IRSTEA (National Research Institute of Science and Technology for Environment and Agriculture), UR RECOVER (Risks, Ecosystems, Vulnerability, Environment and Resilience division), 3275 route de Cézanne, Aix-en-Provence, 13182,France,li-hua.luu@irstea.fr

\section{Pierre Philippe}

IRSTEA (National Research Institute of Science and Technology for Environment and Agriculture), UR RECOVER (Risks, Ecosystems, Vulnerability, Environment and Resilience division), 3275 route de Cézanne, Aix-en-Provence, 13182, France, pierre.philippe@irstea.fr

\section{Sébastien Gourdier}

BRGM (French Geological Survey), DRP (Risks and Prevention Division), 3 avenue Claude Guillemin, BP 36009 , Orléans,45060,France,s.gourdier@brgm.fr

\begin{abstract}
The Loire River basin is regularly impacted by sinkholes because of its specific geological context, karstic limestone overlain by soft cover deposits. The intense rainfall event and the associated floods that occurred in this area in May and June 2016 triggered tens of sinkholes in a few square kilometers. At least 20 houses, one flood protection dyke of the Loire River and two highways were damaged by collapses. These events highlight not only the vulnerability of the area, especially in the case of a disastrous flood of the Loire River, but also the unexpected kinetics of the collapse process.
\end{abstract}

Two different types of sinkholes occurred in the impacted areas: north of Orléans, collapses of the filling of vertical caves are suspected; in the Loire valley, the flood accelerated the internal erosion of alluvium in the karstic active network, triggering cover collapses (spatial and temporal sinkhole frequency increased by an estimated factor of 16,000 to 24,000 ).
In parallel, an innovative internal erosion numerical modeling approach, based on Discrete Element-DEM and Lattice Boltzmann methods - LBM, has been developed through a partnership between the French Geological Survey (BRGM) and the Environment and Agriculture National Research Institute (IRSTEA). The upward propagation of cavities within the cover were successfully simulated. The role of different parameters (soft cover cohesion, hydraulic head, system geometry, etc.) in the sinkhole occurrence were tested by a parametric analysis.

\section{Introduction}

A large amount of water is usually considered to be an aggravating factor for the occurrence of sinkholes (Hyatt et al., 1996; Gordon et al., 2012). In France, the meteorological event of spring 2016 constitutes a new example of that assertion. Beyond the simple statement, lessons learned from this event enabled the French Geological Survey (BRGM) and the Environment and Agriculture National Research Institute (IRSTEA) to improve the understanding of internal erosion processes. 


\section{General \& Geological Context The Beauce Karstified Limestone}

The city of Orléans is located $130 \mathrm{~km}$ south of Paris, in the Loire Valley. The Beauce limestone, a 50 to $90 \mathrm{~m}$ thick Tertiary lacustrine limestone, constitutes the geological bedrock (Lorain, 1973). On both sides of the Loire Valley, the Beauce limestone is overlain by other Tertiary sediments (a few meters thick) and the groundwater level is between 10 to $20 \mathrm{~m}$ deep. In the Loire floodplain, the limestone is mantled by Quaternary alluvium (5 to $15 \mathrm{~m}$ thick) (Figure 1). In these areas, the groundwater level is near the ground surface.

An extensive karstic cave network is assumed to underlie the area but, except for a few sites, our knowledge of network configuration is relatively poor. Speleological investigations are limited by the very few cave entrances and the water-filled nature of the karst system. The exceptions are the Loiret springs where about $4.3 \mathrm{~km}$ of passages have been explored by scuba divers
(Boismoreau, 2008) and some caves in the Orléans Forest (Moreau, 2002). Sinking stream, springs and the sinkhole activity in the $170 \mathrm{~km}^{2}$ of the Loire floodplain around Orléans attest also to the current activity in the Beauce limestone karst terrain (Figure 1). Total water losses from the Loire to the karst aquifer are between 7 and $20 \mathrm{~m}^{3} \cdot \mathrm{s}^{-1}$ (Gutierrez and Binet, 2010). Water returns to the Loire River by springs and rivers (Lepiller, 2006), such as the Loiret River.

\section{Sinkhole History in the Orléans Area}

Studies undertaken since 1903 counted approximately 640 sinkholes in the Loire floodplain around Orléans (Gombert et al., 2015; Perrin et al., 2015; Figure 1). The latest reported sinkholes occur at a rate of 3 to 4 per year. A lot of them are probably backfilled without official reporting. Thus, the minimal sinkhole frequency is approximately 0.02 to 0.03 occurrences per square kilometer per year. The mean diameter of the holes is 1 to $2 \mathrm{~m}$ but can

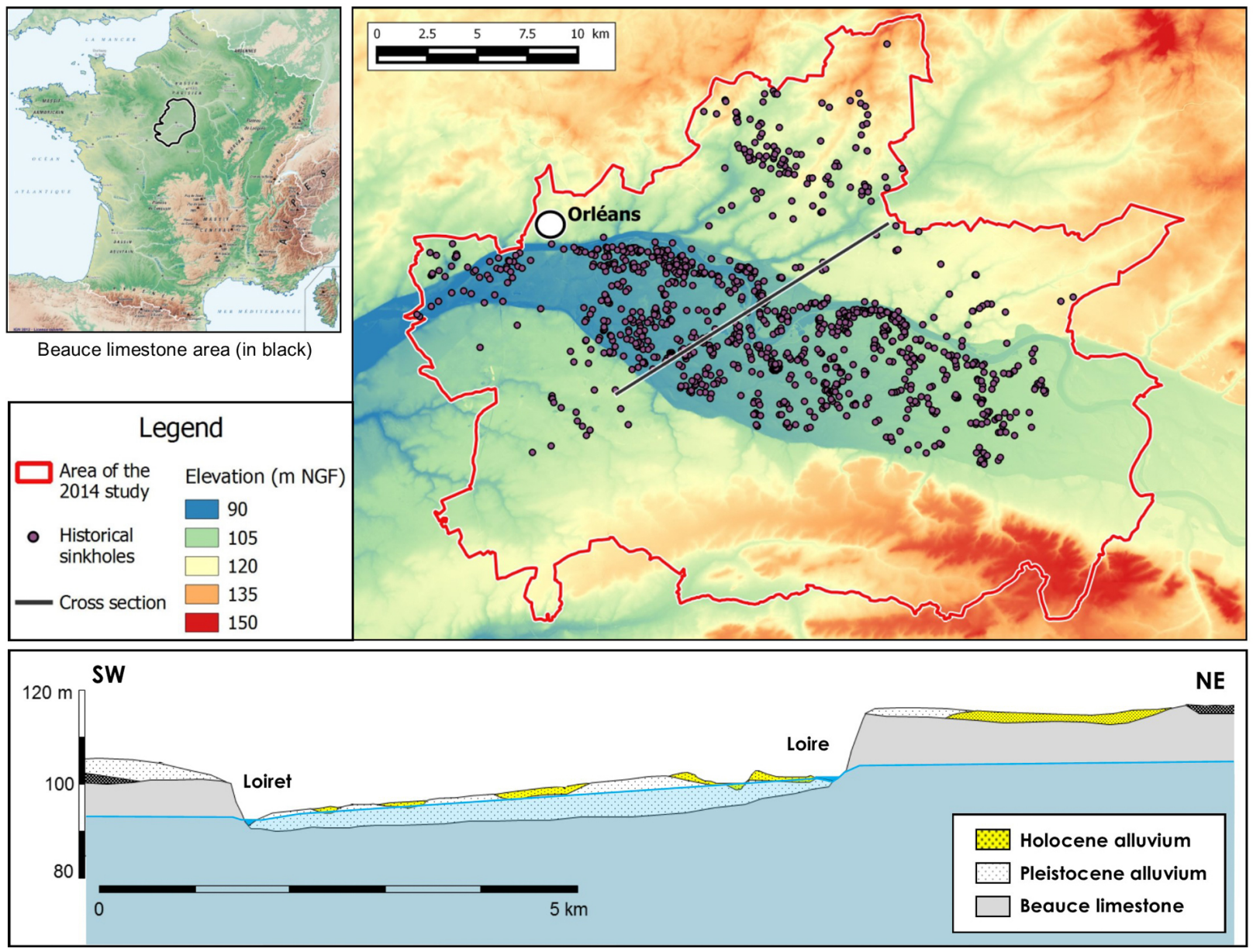

Figure 1. Map of geological context and sinkholes in the Orléans area, and geological cross section through the Loire floodplain. 
be much larger; the biggest recent sinkhole was $16 \mathrm{~m}$ in diameter and $7.5 \mathrm{~m}$ in depth. It occurred in 2010 at Saint-Pryvé-Saint-Mesmin and destroyed a house, fortunately without casualties (Gutierrez et al., 2010). The collapse mechanism is interpreted to be mainly soil piping (or suffosion: downwashing of alluvium by water towards cavernous bedrock with relatively small and poorly connected voids - not necessarily well-developed and -integrated cave networks), followed by the collapse of the thin residual soil layer. This phenomenon is likely not sufficient to explain the biggest sinkholes, unless there is a concentration of voids in a small area. For that kind of event, the collapse of the limestone is also probable (bedrock collapse). An unusually high dissolution rate in the limestone was recently postulated and could be an additional destabilizing factor (estimated dissolution of $1 \mathrm{~cm}$ per year for a $1 \mathrm{~m}^{2}$ cave in which calcium concentrations were measured and compared to those obtained in Loire River (Perrin et al., 2017).

Outside the Loire floodplain, the other parts of the Orléans area seem much less sensitive to the sinkhole collapses, except for the Orléans Forest where hundreds of sinkholes are known (not shown on Figure 1). Speleologists have excavated some of them. All seem to be old cave entrances, naturally filled by sediments and apparently stable (Moreau, 2002). Without infrastructure and other cultural influences, the area is less surveyed than the Loire floodplain, that is until the 2016 meteorological event occurred.

\section{Spring 2016 Meteorological Event and Its Consequences \\ Massive Rainfall and Triggered Floods}

Between May 28 and June 1, 2016, northern France was affected by massive rainfall. In the Orléans area, around $140 \mathrm{~mm}$ were recorded during these five days, the equivalent of three normal rainy months. River floods occurred. For example, Paris saw the highest level of the Seine River since 1982 (Boizard et al., 2016).

In northern Orléans, most part of the rainwater ran off the saturated soil surface towards the Retrève dry valley. Thirty $\mathrm{km}$ were flooded for the first time since 1982 (Figure 2 - Gidy area). The area was severely impacted for two weeks, including the main highway between Orléans and Paris, four small towns and an industrial park. The public and industrial financial losses were estimated at $€ 20$ million (private losses are unknown).

Near the Loire River, a $1-\mathrm{km}^{2}$ area located on the Loire floodplain was flooded by the overflow of an artificial canal (Figure 2 - Chécy area). One to $2 \mathrm{~m}$ of water covered a recently built neighborhood, the watertreatment plant and several fields for 10 days.

\section{Karst Sinkholes Triggered by Rainfall and Floods: Two Postulated Processes}

A cascading effect of rainfall and floods produced around a hundred sinkholes that formed immediately or a few days after the meteorological event (Figure 3). BRGM and two other public institutions were called to help local authorities to ensure public safety. Sixty percent

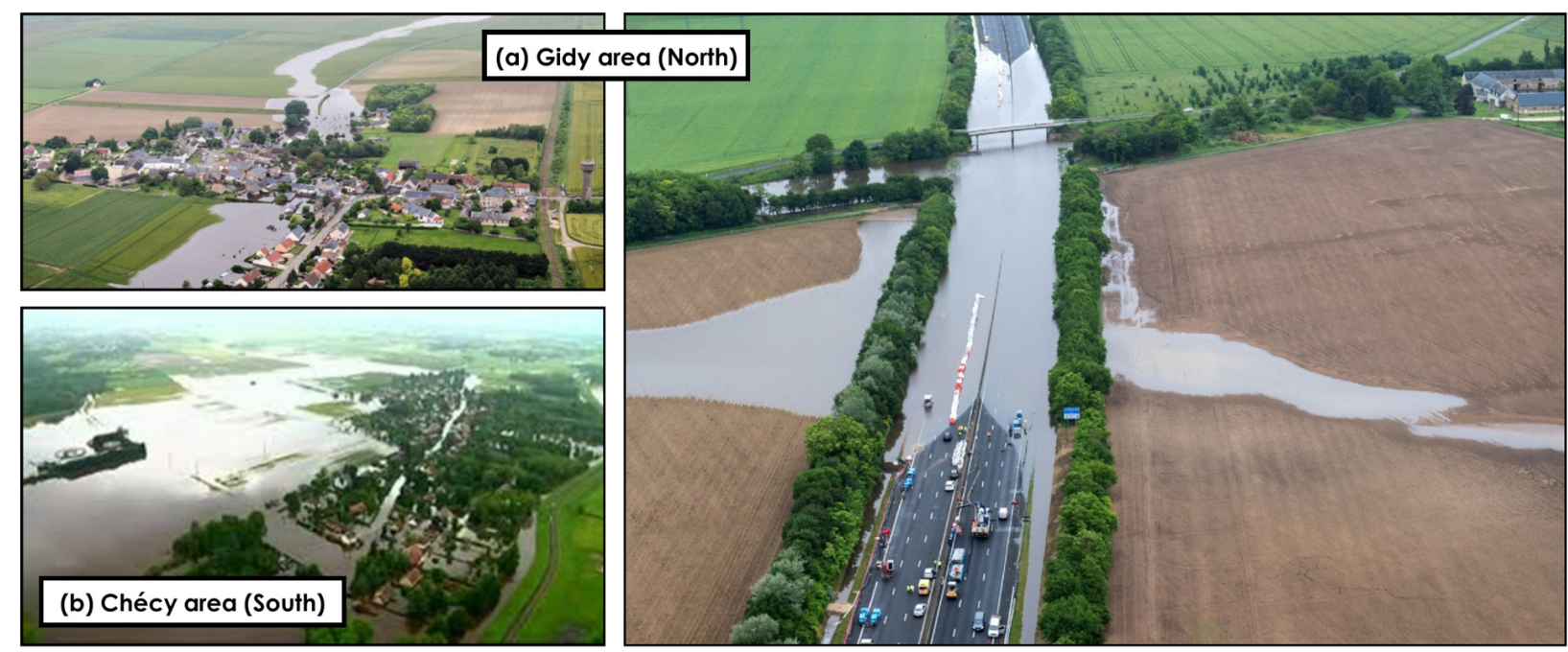

Figure 2. Flooded areas during the spring 2016 meteorological event. (a) Gidy area: flood of the Retrève dry valley. (b) Chécy area: flood by the overflow of an artificial canal. 


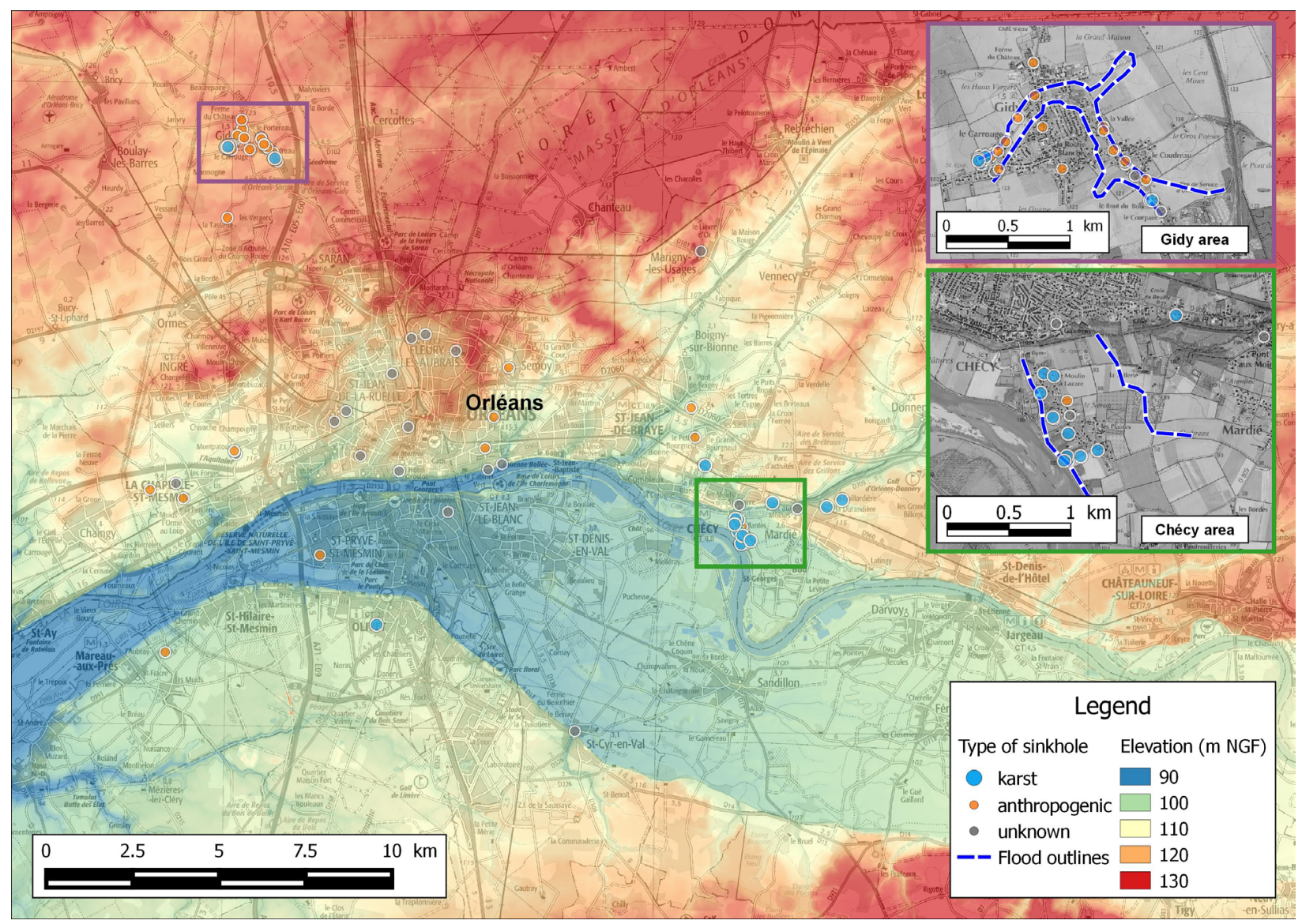

Figure 3. Map of sinkholes triggered by the spring 2016 meteorological event.

of the sinkholes were concentrated in the two-flooded areas of Gidy and Chécy, the others were distributed in the rest of the Orléans urban area and in the countryside. Twenty-five percent of the sinkholes seriously affected buildings or roads (restricted areas).

Based on local expertise and scientific investigations, half of the sinkholes were caused by anthropogenic cavities (failures of abandoned quarries and cellars, soil suffosion in small underground constructions). A quarter of the sinkholes, including some of the largest, were associated with karst collapses. The origins of the remaining quarter remain unknown.

Five karst sinkholes were around $10 \mathrm{~m}$ in diameter and 2 to $3 \mathrm{~m}$ in depth (Figure 4). Most of the other karst sinkholes are around 1 to $2 \mathrm{~m}$ in diameter and less than $1 \mathrm{~m}$ in depth.

In the Gidy area, the occurrence of karst sinkholes was unexpected: not a single similar event has been recently recorded in northern Orléans.
The Chécy area, located in the Loire floodplain, is, in contrast, more prone to sinkhole occurrence (see above), but the frequency (spatial and temporal) was unusually high. The sinkhole occurrence rate evaluated in "normal" conditions ( 0.02 to 0.03 per square kilometer per year), was accelerated by a factor of 16,000 to 24,000 because of the flood (13 sinkholes in one $\mathrm{km}^{2}$ during the 10 days flood $\Rightarrow$ sinkhole occurrence rate $=470$ sinkholes per square kilometer per year).

Considering the two geological terrains affected by floods and the contrasting karst activity in these two areas, two different processes are assumed:

- In the Chécy area, the flood-induced vertical flow in the soil increased the suffosion of alluvium into pre-existing and active karst caves. We hypothesized that the water load may also have triggered the final collapse of the thin residual layer.

- In the Gidy area, the thickness of the altered cohesive limestone layer overlying the caves $(\approx 15 \mathrm{~m})$ would not permit that kind of internal erosion observed in the Chécy area. Our 

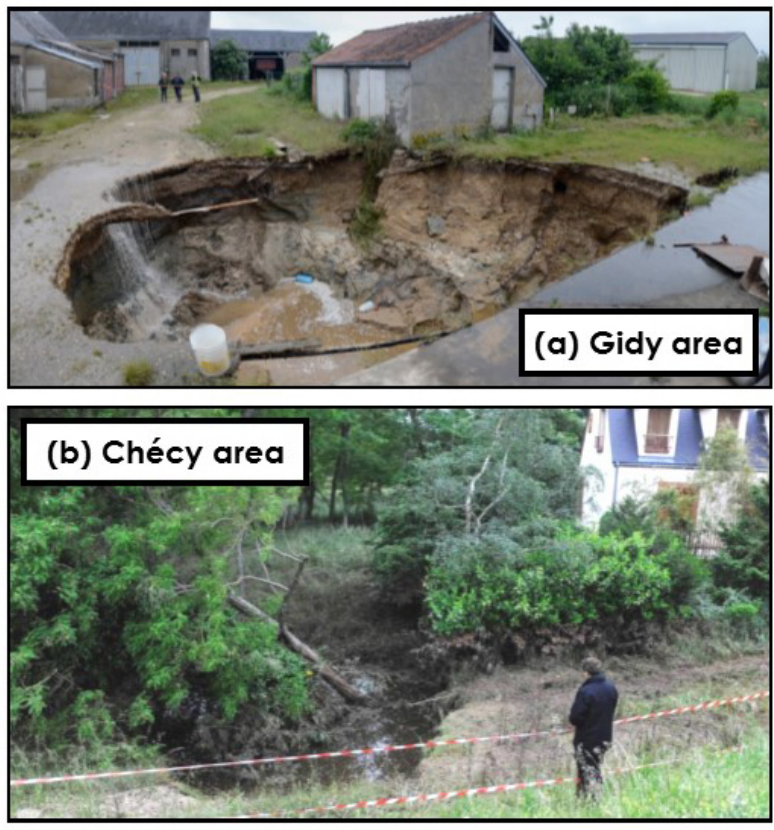

Figure 4. Two major sinkholes triggered by floods.

hypothesis is that the collapse of a formerly vertical cave filled by sediments or backfills caused sinkholes to develop (Figure 5a).

\section{Perspectives for a Better Karst Sinkhole Risk Management}

Although there were no fatalities, the consequences of these karst sinkholes were not negligible. The direct financial losses are estimated around $€ 1$ million (three uninhabitable houses, underpinning of five other houses and industrial buildings, road rebuilding, backfilling of sinkholes).

Moreover, these events reveal the extreme sensitivity of the Loire floodplain to the sinkhole phenomenon. The high flood induced sinkhole occurrence rate (470 per square kilometer per year - see above) might trigger thousands of collapses in the $170-\mathrm{km}^{2}$ area in case of an exceptional flood of the Loire (200-year return period) that could destroy old protection dykes. Such dramatic floods occurred 3 times in 20 years in the $19^{\text {th }}$ century (not in the last 150 years). Furthermore, breaches in the old protection dykes formed during these historic events may have been triggered by karst sinkhole collapses.

BRGM is working on different studies to improve numerical modeling of internal processes resulting in ground collapses.
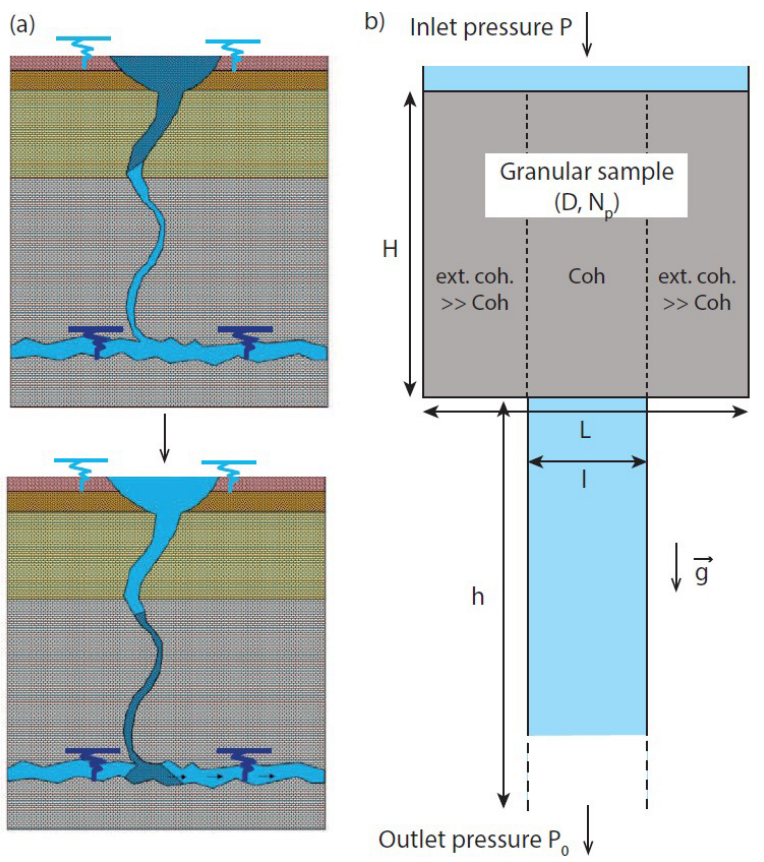

Figure 5. (a) Field situation of soil collapse within a flooded underground conduit. (b) Scenario for the numerical modeling. See Figure 6 for description of the parameters.

\section{Numerical Modeling of the Internal Process The BRGM-IRSTEA Partnership}

As part of the nation-wide studies on dyke stability, the IRSTEA is used to perform numerical modeling and laboratory experimentation of the horizontal internal erosion, resulting in weakening or failure of these sensitive earthworks. In 2016, the BRGM and the IRSTEA began a scientific partnership to adjust the horizontal modeling in order to address the vertical internal erosion in the covered karst terrains (Luu et al., 2017).

\section{Numerical Model}

The model combines the Lattice Boltzmann Method (LBM) and the Discrete Element Method (DEM) to describe efficiently the flow of the fluid phase (LBM) and the movement of the solid phase (DEM).

The LBM is an explicit 2D finite difference scheme over a discrete lattice mesh (Boltzmann equation) that involves the collision and propagation of fluid particles. The soil is considered as cemented granular materials and modeled using a 2D Discrete Element Method, which includes cohesion via solid bonds between particles (Jiang et al., 
2013). When a contact force reaches the yield strength, the bond is broken and the contact becomes purely frictional via a Kelvin-Voigt relationship, which models the normal force and a viscous-regularized Coulomb law for the shear force.

To deal with the solid-fluid coupling, a relationship based on a momentum-exchange method is used (Feng, 2007). The simulation setup consists of a conduit initially clogged by an immersion (Figure 5a). In order to impose a preferential path for the flow within the granular sample, two soil cohesions are used. In the external layers, the bond strength is fixed at $\mathrm{C}=1000 \mathrm{~N}$, whereas in the central layer, cohesion varies between 5 to $20 \mathrm{~N}$. The erosion of the soil layer is triggered by a pressure gradient.

Two scenarios are simulated (same diameter grains, same height, two different lengths L, corresponding to particle numbers $\mathrm{Np}=11816$ and 3042 - see Figure 6).

Thereafter, the soil cohesion is characterized by a dimensionless cohesion number defined as the ratio between bond strength to the particle's buoyant weight: $\mathrm{C}_{\mathrm{oh}}=\mathrm{C} /\left(\rho_{\mathrm{s}}-\rho_{\mathrm{f}}\right) \mathrm{gV}$, where $\rho_{\mathrm{s}}-\rho_{\mathrm{f}}$ is the submerged apparent density, $\mathrm{g}$ is the gravitational acceleration and $\mathrm{V}$ is the particle's volume. The initiation of motion in sediments is classically analyzed by defining the Shields number (ratio of fluid force on the particle to the weight of the particle). For the cemented soil modeled here, this criterion should be extended by introducing the cohesion number Coh. Work is under way to further define this issue.

\section{Erosion Regimes}

The behavior of the granular layer subjected to a pressure gradient is parametrically studied. Figure 6 reports the implemented parameters. By varying the conduit size $\Delta(\Delta=1 / D)$, the granular cohesion $\left(\mathrm{C}_{\mathrm{oh}}\right)$ and the inlet fluid pressure $(\mathrm{P})$, two situations are observed: a "blocking" stable case (no erosion) or an intermittent evacuation of the granular sample through the predefined internal conduit.

This phenomenon is separated into three different erosion regimes (Figure 7). At the lowest magnitude of erosion, a stable cavity is marginally formed. If erosion parameters increase, an upward internal erosion mechanism arises, where the destabilization front direction is opposite to the flow direction. Finally, plug collapse occurs where the whole granular column falls all at once, but not under its own weight. A bond breakage along the conduit, due to erosion triggered by the hydraulic gradient, precedes this collapse.

Three phase diagrams related to the conduit size $(\Delta)$, the cohesion number $\left(\mathrm{C}_{\mathrm{oh}}\right)$ and the inlet pressure $(\mathrm{P})$ for the two samples are illustrated in Figure 8. We indicate the erosion threshold by the lines. Globally, a high enough conduit size, a high enough inlet pressure and a small enough cohesion can trigger the erosion process. The first diagram shows that the higher $\mathrm{C}_{\text {oh }}$, the higher $\Delta$ is required to erode soil. As regards the eroding effect of increasing $\mathrm{P}$, the two other diagrams display very sharp thresholds. This observation needs additional studies.

The simulations also point out the influence of the granular sample length $\mathrm{L}$ on the erosion threshold. The latter is slightly "delayed" for the smaller sample, in the sense that for a higher critical $\Delta$, a smaller critical $\mathrm{C}_{\text {oh }}$ and a higher critical $\mathrm{P}$ are involved in the erosion process. To capture the physics underlying this result, work is under way, focusing on the inter-particle cohesion, in order to monitor how microscale behavior leads to bond rupture.

\begin{tabular}{llll}
\hline Solid phase & & Fluid phase & \\
\hline Particle mean diameter, $\mathrm{D}$ & $6 \cdot 10^{-3} \mathrm{~m}$ & Conduit length, $\mathrm{l}$ & {$[3-27] \cdot \mathrm{D}$} \\
Polydispersity, $\mathrm{D}_{\max } / D_{\min }$ & 1.5 & Conduit height, $\mathrm{h}$ & $100 \cdot \mathrm{D}$ \\
Granular sample length, $\mathrm{L}$ & $33 \cdot \mathrm{D}, 67 \cdot \mathrm{D}$ & Inlet pressure, $\mathrm{P}$ & {$[0-2000] \mathrm{Pa}$} \\
Granular sample height, $\mathrm{H}$ & $70 \cdot \mathrm{D}$ & Outlet pressure, $\mathrm{P}_{0}$ & $0 \mathrm{~Pa}$ \\
Particle density, $\rho_{s}$ & $2.2 \cdot 10^{3} \mathrm{~kg} / \mathrm{m}^{3}$ & Fluid kinematic viscosity, $v$ & $4 \cdot 10^{-5} \mathrm{~m}^{2} / \mathrm{s}$ \\
Normal, shear and rolling stiffnesses $\mathrm{k}_{n}=k_{s}=10 \cdot \mathrm{k}_{w}$ & $1.1 \cdot 10^{5} \mathrm{~N} / \mathrm{m}$ & Fluid density, $\rho_{f}$ & $8.5 \cdot 10^{2} \mathrm{~kg} / \mathrm{m}^{3}$ \\
Friction coefficients, $\mu=3 \cdot \mu_{w}$ & 0.3 & Lattice grid size, $\Delta x$ & $6.3 \cdot 10^{-4} \mathrm{~m}$ \\
Damping coefficient, $\eta$ & $68.3 \mathrm{~kg} / \mathrm{s}$ & Lattice speed, $\mathrm{c}_{s}$ & $10 \mathrm{~m} / \mathrm{s}$ \\
Bond stiffnesses, $\mathrm{k}_{n, b}=0.4 \cdot \mathrm{k}_{s, b}$ & $0.5 \cdot \mathrm{k}_{n}$ & Hydraulic radius factor, $\mathrm{R}_{h}$ & 0.8 \\
Bond strength, $\mathrm{C}=\mathrm{C}_{n}=2 C_{s}$ & {$[5-20] \mathrm{N}$} & & \\
\hline
\end{tabular}

Figure 6. Geometrical, solid and fluid model parameters implemented in the simulations. 


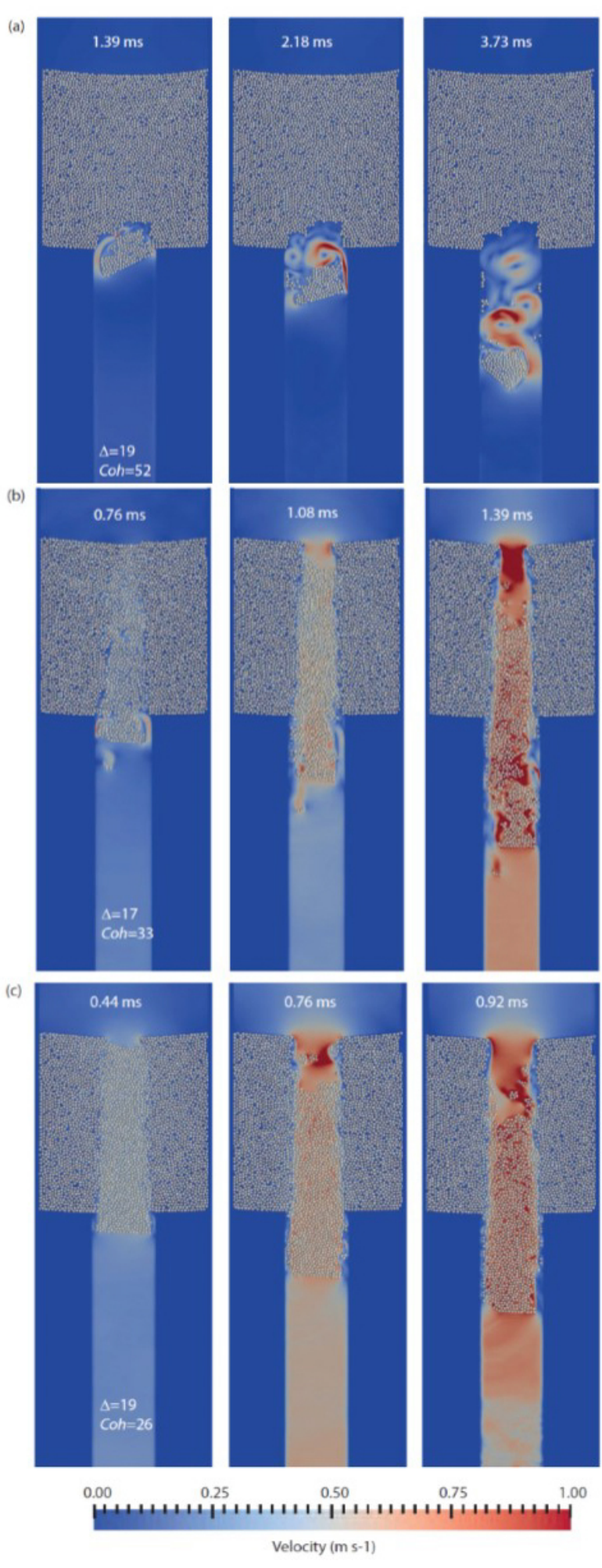

Figure 7. Erosion regimes: (a) stable cavity, (b) progressive collapse, (c) plug collapse.

\section{Conclusion}

The sinkholes triggered by the spring 2016 meteorological event prove the vulnerability of the Orléans area to cavity collapses. The last two years of research on development of karst sinkholes, led by the BRGM, addresses understanding of the soil particle behavior (thanks to the IRSTEA) to the on-site responses in an emergency. This multi-scale study is promising for the future. Improving the prediction of where, why and when a sinkhole will occur is a work in progress. Linking the numerical modeling illustrated here to "geotechnical" reality will be a significant step in characterizing sinkhole hazards and risks. It will be done through improving the parametric studies and developing experimental tests. The model is already providing an excellent visual medium (video) to explain the sinkhole phenomenon to the general population. Informing and educating the public is an important task in improving risk management (outreach). New scientific studies on the Loire floodplain began on the basis of these perspectives.

\section{References}

Boismoreau P. 2008. Les sources du Parc Floral. Spéléologie Subaquatique Loiret 10.

Boizard P, Ricard F. 2016. Coupure de l'autoroute A10 et autres infrastructures lors des inondations de fin mai 2016. Rapport final du Conseil Général de l'Environnement et du Développement Durable (Ministère de l'Environnement, de l'Energie et de la Mer). Rapport 010735-01.

Feng YT, Han K, Owen DRJ. 2007. Coupled lattice Boltzmann method and discrete element modelling of particle transport in turbulent fluid flows: Computational issues. International Journal for Numerical Methods in Engineering 72 (9): 1111-1134.

Gombert P, Orsat J, Mathon D, Alboresha R, Al Heib M, Deck O. 2015. Rôle des effondrements karstiques sur les désordres survenus sur les digues de Loire dans le Val d'Orléans (France). Bulletin of Engineering Geology and the Environment 74 (1): 125-140.

Gordon DW, Painter JA, and McCranie JM 2012. Hydrologic conditions, groundwater quality, and analysis of sinkhole formation in the Albany area of Dougherty County, Georgia, 2009. US Geological Survey Scientific Investigations Report 2012-5018.

Gutierrez A, Binet S. 2010. La Loire souterraine: circulations karstiques dans le val d'Orléans. Géosciences 12: 42-53. 

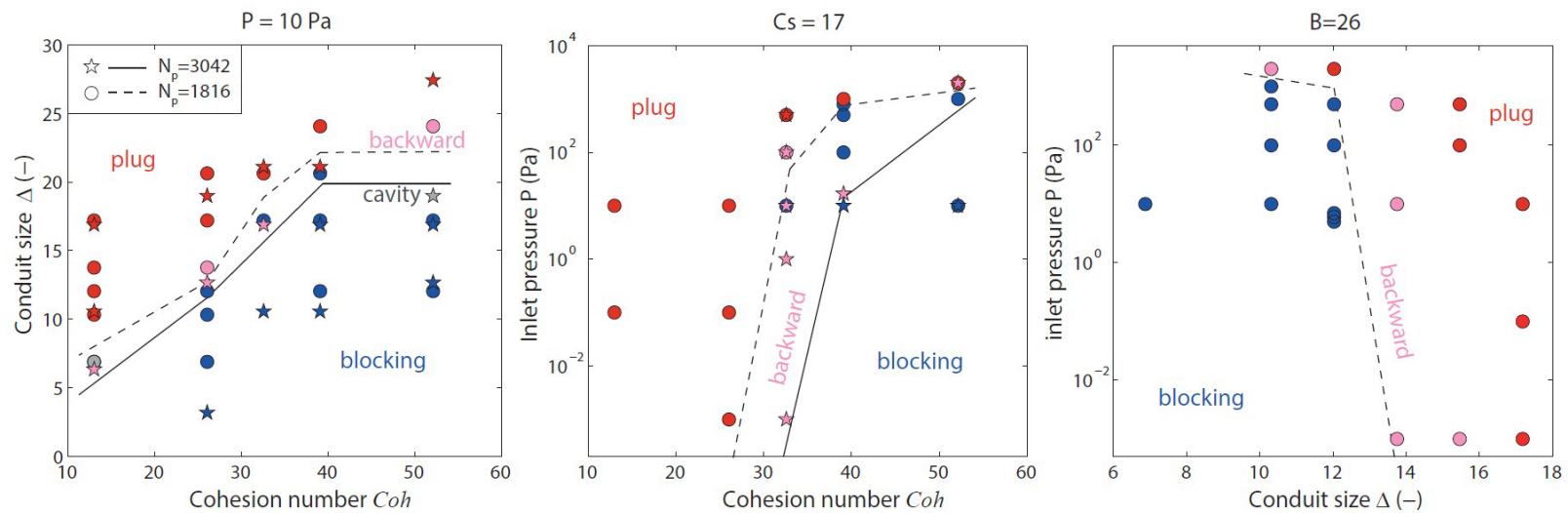

Figure 8. Phase diagrams: influence of the conduit size $\Delta(\Delta=I / D$, see above), the cohesion number $C_{o n}$ and the inlet pressure (P) on the different features, namely the blocking (blve), the cavity (grey), the backward extrusion (pink) and the plug extrusion (red).

Hyatt JA, Jacobs PM. 1996. Distribution and morphology of sinkholes triggered by flooding following Tropical Storm Alberto at Albany, Georgia, USA. Geomorphology 17 (4): 305-316.

Jiang M, Zhang W, Sun Y, Utili S. 2013. An investigation on loose cemented granular materials via DEM analyses. Granular Matter 15 (1): 65-84.

Lepiller M. 2006. Val d'Orléans. Aquifères et eaux souterraines en France 1: 200-214.

Lorain JM. 1973. La géologie du calcaire de Beauce. Le Calcaire de Beauce. Bulletin de liaison des laboratoires des Ponts et Chaussées. Spécial U.

Luu LH, Philippe P, Noury G, Perrin J, Brivois O. 2017. Erosion of cohesive soil layers above underground conduits. Proceedings of the 8th International Conference on Micromechanics of Granular Media; Montpellier, France.

Moreau J. 2002. Les gouffres du nord d'Orléans. Groupe spéléologique orléanais. Bulletin 7: 1-28.

Perrin J, Cartannaz C, Noury G, Vanoudheusden E. 2015. A multicriteria approach to karst subsidence hazard mapping supported by weights-of-evidence analysis. Engineering Geology 197: 296-305.

Perrin, J, Pasquier S, Gutierrez A, Salquebre D, Vanoudheusden E, Joigneaux E, Binet S. 2017. Investigating physical processes leading to sinkhole occurrence in Val d'Orléans (France). In EuroKarst 2016, Neuchâtel (pp. 79-86). Springer, Cham. 